\title{
Inflation targeting and the cyclicality of monetary policy
}

\author{
By \\ John Thornton \\ The Business School, Bangor University, Bangor LL57 2DG, UK. \\ Email: j.thornton@bangor.ac.uk \\ (Corresponding author) \\ and \\ Chrysovalantis Vasilakis \\ The Business School, Bangor University, Bangor LL57 2DG, UK \\ Email: c.vasilakis@bangor.ac.uk \\ and \\ Institut de Recherches Economiques et Social, \\ Université Catholique de Louvain
}

\begin{abstract}
We assess whether the adoption of inflation targeting (IT) frameworks has facilitated countercyclical monetary policies in a sample of 90 industrial and developing economies, 22 of which have adopted IT. Using propensity score matching methods, we show that the average treatment effect of IT has a statistically significant and quantitatively quite large effect in facilitating a more countercyclical monetary policy IT countries.
\end{abstract}

JEL classification: E4, E5

Keywords: Inflation targeting, monetary policy cyclicality, treatment effect, propensity score matching

Word count: 2968 


\section{Introduction}

It is well documented that many-mainly developing — economies pursue procyclical macroeconomic policies that amplify the business cycle. Particular attention has been paid to the cyclical nature of fiscal policy in developing economies, with ample evidence that this typically has been procyclical (e.g., Alesina, Campante, and Tabellini 2008). The recent literature relating to the cyclicality of monetary policy arrives at broadly similar conclusions - that is, monetary policy also is generally countercyclical in industrial economies and procyclical in developing economies with tentative evidence of a transition to countercyclical monetary policy in some of the latter (Frankel 2011; McGettingham, Moriyama, Ntsama, Painchard, Qu and Steinberg, 2013; Vegh and Vuletin 2013). ${ }^{1}$ In this paper, we expand the empirical literature on the determinants of monetary policy cyclicality by examining the role of monetary regimes. Specifically, we look at whether the adoption of an inflation targeting (IT) regime has facilitated the procyclicality of monetary policy by evaluating the treatment effect of IT on monetary policy cyclicality using propensity score-matching methods, which have the advantage of avoiding the 'self-selection problem' that can give rise to biased results.

There are several reasons for believing that adoption of an IT regime could facilitate procyclical monetary policy. The first and probably most important reason is the impact of IT on monetary policy credibility: adopting a single mandate such as IT can be an effective way for a central bank that cannot commit to overcome the classic timeinconsistency problem. Policy credibility should be enhanced by the rules-based approach of IT and its emphasis on transparency and accountability relative to other monetary frameworks. Recent research suggests IT adoption has positive credibility 
effects, for example, as measured by subsequent developments in government borrowing costs (Palomino, 2012; Thornton and Vasilakis 2016). Second, the exchange rate flexibility inherent in IT should reduce the sensitivity of interest rates in so far it provides a mechanism for the correction of external imbalances not available with an exchange rate peg (Jahjah, Wei, and Yue 2013). Third, the adoption of IT may signal a commitment to economic reforms and sounder macroeconomic policies (Roger 2010). Finally, because of the constraint that an IT framework imposes on seigniorage revenues, IT adoption could result in better fiscal discipline and fiscal reforms that boost fiscal revenue and contain spending (Minea and Tapsoba 2014). ${ }^{2}$

Formal empirical evidence on the impact of IT on the cyclicality of monetary policy appears to be limited to McGettingham, Moriyama, Ntsama, Painchard, Qu, and Steinberg (2013). They apply panel regression techniques to 64 developing and highincome countries during the period 1985-2011 and report that countries that have adopted an IT framework tend to have more countercyclical monetary policy - that is, they find an improvement in the correlation coefficient between real interest rates and output in these countries. A drawback of this study is that it ignores the self-selection problem of policy adoption that arises when a country's targeting choice is nonrandom and can lead to biased estimates. In particular, systematic correlation between the targeting choice and other covariates will cause the selection-on-observables problem, which can lead to biased estimates. We find evidence for the existence of this problem with an IT dummy in probit estimates being systematically correlated with variables such as macroeconomic performance, the level of public debt, the level of financial development, and the exchange rate regime. To address the self-selection problem, we evaluate the treatment effect of IT on monetary policy cyclicality making use of 
propensity score-matching methods. Our results indicate that IT has reduced procyclicality by about 11 per cent of the correlation between the cyclical components of output and real interest rates.

\section{Methodology}

We test the impact of IT adoption on the cyclicality of monetary policy by examining developments in a 10-year rolling window correlation between the cyclical component of real GDP and the cyclical component of the real short-term interest rate, where the latter is our proxy for the stance of monetary policy. ${ }^{3}$ A positive correlation is indicative of countercyclical monetary policy, while a negative correlation indicates procyclical monetary policy. The treatment group comprises 22 advanced and developing economies that had adopted IT by the end of 2014. We draw on Hammond (2012) for a listing of countries that adopted IT and for the adoption dates. The control group comprises 68 non-IT countries for which we could access data on interest rates and the different control variables. 10-year rolling window correlations between the cyclical components of real interest rates and real GDP for the IT and non-IT countries are shown in Table $1 .^{4}$ The table shows the average correlation for the pre- and post-IT periods for the inflation targeting countries, and for pre- and post-1999 for the non-IT countries, with 1999 chosen simply because this is the mean year of IT adoption by the inflation targeting countries. In both IT and non-IT countries, monetary policy became more countercyclical on average (i.e., the correlation coefficients increased). Annual developments in the average rolling correlation coefficients for IT and non-IT countries are shown in Figure 1. Again, there appears to be little to choose between their experiences, with convergence in the average correlation coefficients after 2007 and 
suggestions of more procyclical policies during the 2007-2009 financial crisis and more countercyclical policies thereafter.

We make use of four propensity score-matching methods that have been applied recently to macroeconomic policy evaluations (e.g., Glick, Guo, and Hutchinson 2006, Lin and Ye 2007 2009). The first is the nearest-neighbour matching with replacement, which matches each treated country to the $\mathrm{N}$ control countries that have the closest propensity scores. We employ two nearest-neighbour matching estimators: $n=1$ and $n$ $=3$. The second method is radius matching, which performs the matching based on estimated propensity scores falling with a certain radius $\mathrm{R}$. We use a wide radius ( $r=0.05)$, a medium radius ( $r=0.03)$, and a tight radius $(r=0.01)$. The third method is the kernel matching method, which matches a treated group country to all control group countries weighted in proportion to the closeness between the treated group country and the control group country. The fourth method is the regression adjusted local linear matching method.

\section{Estimating the average treatment effects}

We first estimate the propensity scores using a probit model in the probability of adopting an IT framework is conditional on a group of control variables:

$$
P\left(Y_{i t}=1 \mid X_{i t}=\phi\left(X_{i t}^{\prime} \beta\right)+\eta_{i t}\right.
$$

where $Y_{i t}$ is a 0,1 dummy variable for the adoption of an IT regime (where 1 indicates IT adoption), $X_{i t}$ is a set of control variables, $\phi$ is the cumulative function of the 
standard normal distribution, and $\eta_{i t}$ is the error term. We then utilize the estimated propensity scores to conduct matching to obtain the treatment effects of IT adoption. For the independent variables, we draw on Samarina and de Haan's (2014) analysis of the determinants of a country's decision to adopt an IT framework. Their findings suggest that countries are more likely to adopt IT if they have low inflation, high real GDP growth, a flexible exchange rate regime, are more integrated into the world economy, have a history of fiscal discipline, and have more developed financial markets. Accordingly, the dependent variables in our baseline probit model are: the lagged inflation rate, real GDP growth, the ratios to GDP of public debt, foreign trade, and bank credit to the private sector. In addition, we employ the Chinn and Ito (2006) financial openness index, and a measure of exchange rate regime flexibility, for which we use the Reinhart and Rogoff (2004) course grid classification system. The macroeconomic variables are from the World Bank's World Development Indicators database, and we draw on Abbas, Belhocine, El Ganainy, and Horton (2010) and the IMF's World Economic Outlook database for data on public debt. The results from the probit model are reported in Table 2. The baseline result in column 1 of the table broadly supports the Samarina and de Haan (2014) analysis - that is, IT adoption is more likely in countries that have relatively high rates of GDP growth, relatively low levels of inflation and public debt, are more integrated into the global economy through open trade and capital accounts, and have more flexible exchange rate regimes and relatively deep financial markets.

To ensure greater comparability between the treatment group and the control group, we discard the control group countries whose estimated propensity scores are lower than the lowest score among the treatment group countries. The matching results are 
presented in Table 3, which reports the estimated average treatment effect on the treated (ATTs) of monetary policy cyclicality. The baseline results are in the first row of the table and show that the ATTs are positive, highly statistically significant, and quite large in magnitude at about $11 \%$ of the correlation coefficient. That is, the correlation between the cyclical components of monetary policy (real interest rates) and real GDP rises following the adoption of an IT framework, which we interpret as reflecting a fall in the procyclicality of monetary policy.

We carry out three tests to check the robustness of our finding that IT significantly reduces monetary policy procyclicality in IT-adopting countries. First, we take into account that many countries in the sample (inflation-targeters and non-targeters) experienced financial crises during the period, which likely impacted on the conduct of monetary policy and could bias our results. The probit estimate including a financial crisis dummy is reported in the second column of Table 2. The coefficient on the crisis dummy is not statistically significant, and the associated ATTs reported in the second row of Table 3 remain of the same sign, statistically significant, and of a similar magnitude as the baseline result. Second, to avoid the suspicion that very high rates of inflation in some countries might be driving the results, we dropped high-inflation (above 100 percent) countries from the sample. These probit results are reported in column 3 of Table 2 and are comparable to those for the full sample of countries. The associated ATTs are reported in row 3 of Table 3 and also are largely unchanged in terms of sign, size and statistical significance. Finally, we examine the sensitivity of our results to the country composition of the sample by splitting the sample into industrial and developing economies on the grounds that the latter tend to have had a more volatile experience with respect to output and inflation and they might be expected 
to face greater difficulty in managing the technical challenges of implementing an IT framework. The probit results for industrial and developing countries are reported in columns 4 and 5 of Table 2, respectively. The main differences between the two sets of countries are that GDP growth and open capital accounts levels are not statistically significant factors in the decision by industrial countries of whether or not to adopt an IT framework, and that developing economies are less likely to adopt IT if they have experienced a financial crisis. The associated ATTs are reported in rows 4 and 5 of Table 3 and remain in line with the baseline estimate for the full sample of countries. That is, the adoption of an IT framework appears to reduce the procyclicality of monetary policy in both industrial and developing countries. ${ }^{5}$

\section{Conclusions}

In this paper, we evaluated the treatment effect of IT on the cyclicality of monetary policy in industrial and developing economies. We used propensity score matching methods to show that the average treatment effect of IT on increasing the countercyclicality of monetary policy is statistically significant and quantitatively quite large in IT countries. On average, the adoption of IT has led to a rise in the correlation coefficient between the cyclical components of monetary policy and real GDP of about 11 per cent. This result is robust to controlling for the effects financial crises and removing high-inflation countries from the sample, and appears to be valid for both industrial and developing country IT adopters.

\section{Footnotes}

1. Recent work suggests that greater counter cyclicality might be transmitted by the effects of monetary and macroeconomic policy announcements on liquidity flows (e.g., 
Chordia, Sarkar, and Subrahmanyam 2005; Sensoy 2016) or a pass-through from treasury bills to private yields (Kiley 2016).

2. Of course, not all the evidence is that IT adoption is beneficial. For example, Ball and Sheridan (2005) find no evidence that economic performance (measured by the behavior of inflation, output, and interest rates) improved in adopting countries relative non-adopting countries in a sample of OECD countries; and Thornton (2016) reports that adoption of an IT did not help reduce inflation and growth volatility in developing countries compared to the average experience with other monetary regimes and was no more advantageous in these regards than the adoption of a hard or crawling peg exchange rate regime.

3. See McGettingham, Moriyama, Ntsama, Painchard, Qu and Steinberg, 2013; and Vegh and Vuletin 2013 for similar approaches to measuring the cyclicality of monetary policy.

4. The real interest rate is measured as the average interest rate less the average rate of consumer price inflation; interest rates are mainly central bank discount rates (from the IMF's International Financial Statistics database) because of their longer availability, though in some cases we have data for overnight interbank interest rates. The cyclical components of interest rates and GDP are derived from the average of the estimated trend in each series using a HP filter with lambda 100 and 6.25.

5. At the suggestion of a referee, we also employed an alternative probit model for the probability of adopting an IT framework as the basis estimating the propensity scores, using the 'monetary independence index' (MI index) calculated by Aizenman, Chinn and Ito (2008) in place of the exchange rate regime and financial openness indicators In the probit estimate, the coefficient on the MI index in the probit estimate is positive and statistically significant, indicating that IT adoption is more likely in countries with 
more monetary independence; and the corresponding matching results do not differ substantially from those reported in Table 3. (Results available on request.) 


\section{References}

Abbas S.A., Belhocine, N., El Ganainy, A., Horton, M., 2010. A historical public debt database. IMF Working Paper 10/245.

Alesina, A., Campante, F.R., Tabellini, G., 2008. Why is fiscal policy often procyclical? Journal of the European Economic Association 6: 1006-1036. Aizenman, J., Chinn, M.D., Ito, H., 2008. Assessing the emerging financial architecture: measuring the trilemma's configurations over time. NBER Working Paper 14533.

Ball, L. M., Sheridan, N., 2005. Does inflation targeting matter? In: Bernanke, B.S., Woodford, M. (Eds.), The Inflation-Targeting Debate. University of Chicago Press, pp. 249-282.

Chinn, M.D., Ito, H., 2006. What matters for financial development? Capital controls, institutions, and interactions. Journal of Development Economics 81: 163-92.

Chordia, T., Sarkar, A., Subrahmanyam, A., 2005.An empirical analysis of stock and bond market liquidity. Review of Financial Studies 18: 85-129.

Frankel, J.A., 2011. Monetary policy in emerging markets, in: Freidman B., Woodford, M. (Eds.), Handbook of Monetary Economics, Vol. 3B. North Holland, Amsterdam, pp. 1439-1520.

Glick, R., Guo, X., Hutchison, M., 2006. Currency crises, capital-account liberalization, and selection bias. The Review of Economics and Statistics 88: 698714.

Hammond G., 2012. State of the art of inflation targeting. CCSB Handbook No. 29, Centre for Central Bank Studies, Bank of England. 
Jahjah, S., Wei, B., Yue, V.Z., 2013. Exchange rate policy and sovereign bond spreads in developing countries. Journal of Money, Credit and Banking 45: 1275 1300.

Kiley, M.T., 2016. Monetary policy statements, treasury yields, and private yields: before and after the zero lower bound. Finance Research Letters 18: 285-290. Lin, S., Ye, H., 2007. Does inflation targeting really make a difference? Evaluating the treatment effect of inflation targeting in seven industrial countries. Journal of Monetary Economics 54: 2521-2533.

Lin, S., Ye, H., 2009. Does inflation targeting make a difference in developing countries? Journal of Development Economics 89: 118-123.

McGettingham, D., Moriyama, K., Ntsama, J.N.N., Painchard, F., Qu, H., Steinberg, C., 2013. Monetary policy in emerging markets: taming the cycle. IMF Working Paper 13/96.

Minea, A., Tapsoba, R., 2014. Does inflation targeting improve fiscal discipline? Journal of International Money and Finance 40: 185-203.

Palomino, F., 2012. Bond risk premium and optimal monetary policy. Review of Economic Dynamics 15: 19-40.

Reinhart, C.M., Rogoff, K.S., 2004. The modern history of exchange rate arrangements: a reinterpretation. Quarterly Journal of Economics 119: 1-48. Roger, S., 2010. Inflation targeting at 20: achievements and challenges, in: Cobham, D., Eitrheim, Ø., Gerlich, S., Qvigstad, J.F. (Eds.), Twenty Years of Inflation Targeting: Lessons Learned and Future Prospects. Cambridge, Cambridge University Press, pp. 25-56.

Samarina, A., De Haan, J., 2014. Right on target: exploring the factors leading to inflation targeting adoption. Contemporary Economic Policy 32: 372-89. 
Sensoy, A., 2016. Commonality in liquidity: effects of monetary policy and macroeconomic announcements. Finance Research Letters 16: 125-131.

Thornton, J., 2016. Inflation targeting in developing countries revisited. Finance Research Letters 16: 145-153.

Thornton, J., Vasilakis, C., 2016. Does inflation targeting reduce sovereign risk? Further evidence. Finance Research Letters 18: 237-241

Vegh, C.A., Vuletin, G., 2013. Overcoming the fear of free falling: monetary policy graduation in emerging markets. NBER Working Paper 18175. 


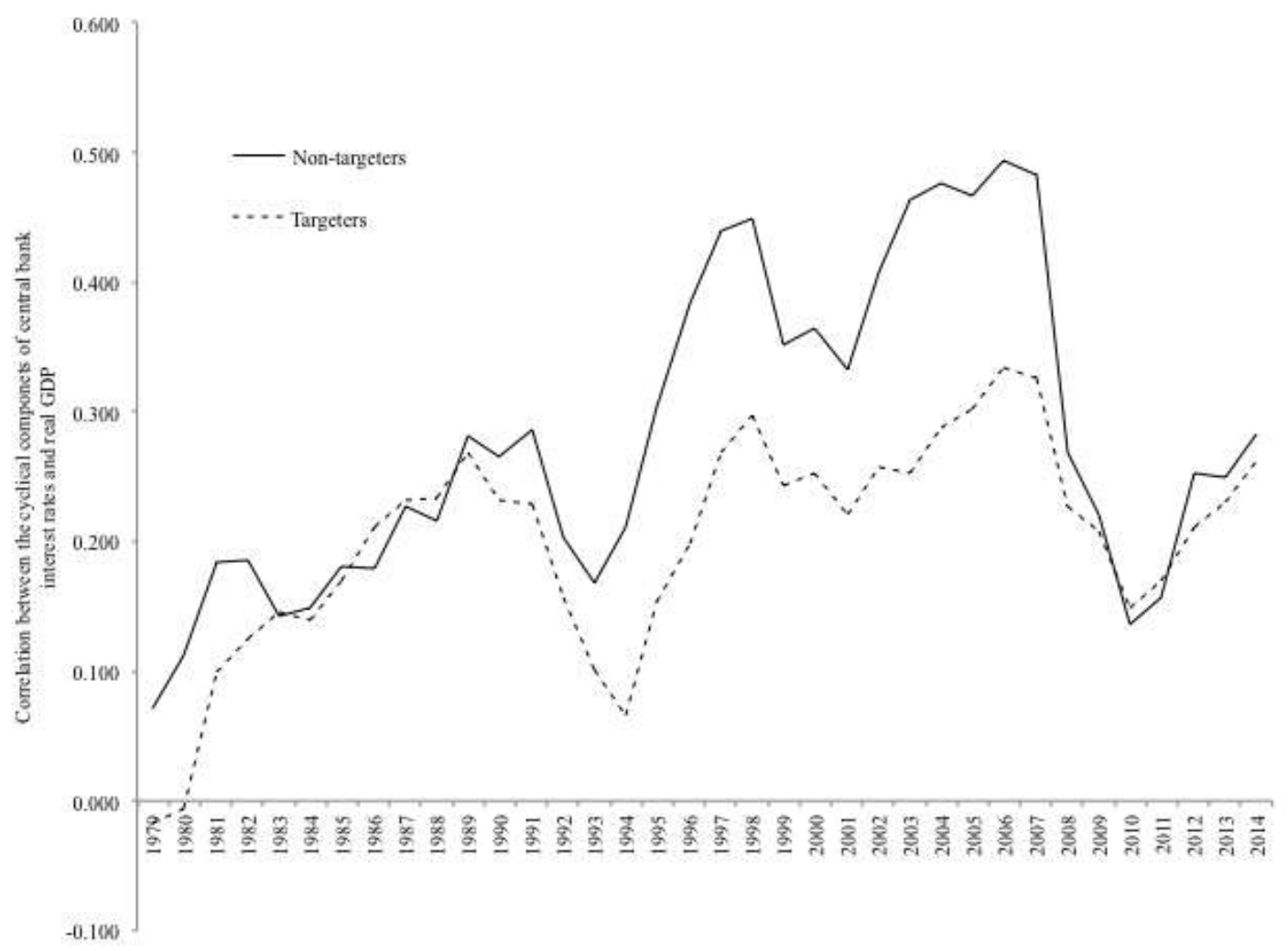

FIGURE 1. Monetary policy cyclicality coefficients in inflation targeting and non-inflation targeting countries 
TABLE 1

TEN-YEAR MOVING CORRELATON COEFFICIENTS BETWEEN THE CYCLICAL COMPONENTS OF THE REAL INTEREST RATE AND REAL GDP, 1979-2014

\begin{tabular}{|c|c|c|c|c|c|c|c|c|}
\hline \multicolumn{5}{|c|}{ Inflation targeting coumtries } & \multicolumn{4}{|c|}{ Non-inflation targeting countries } \\
\hline & $\begin{array}{c}\text { Year inflation } \\
\text { targeting adopted }\end{array}$ & $\begin{array}{c}\text { Pre-inflation } \\
\text { targeting period }\end{array}$ & $\begin{array}{l}\text { Post-inflation } \\
\text { targeting period }\end{array}$ & Change & & Pre-1999 & Post-1999 & Change \\
\hline Australia & 1993 & 0.181 & 0.012 & -12.169 & Algeria & 0.084 & -0.173 & -0.256 \\
\hline Brazil & 1999 & 0.039 & -0.383 & -10.422 & Antigua and Barboda & 0.115 & 0.222 & 0.107 \\
\hline Canada & 1991 & 0.188 & 0.391 & 0.203 & Argentina & 0.005 & 0.086 & 0.081 \\
\hline Chile & 1999 & 0.688 & 0.357 & -0.331 & Austria & 0.155 & 0.391 & 0.236 \\
\hline Colombia & 1999 & 0.297 & 0.656 & 0.359 & Bahrain & 0.169 & -10.333 & -0.503 \\
\hline Ghasa & 1992 & 0.233 & 0.173 & -0.060 & Bangladesh & 0.054 & 0.098 & 0.044 \\
\hline Hungary & 2007 & -0.040 & -0.009 & 0.031 & Barbados & -1).468 & 0.017 & 0.485 \\
\hline Iceland & 20001 & 0.529 & 0.821 & 0.292 & Belgitam & 0.541 & 0,454 & $-0,087$ \\
\hline Indonesia & 2005 & 0.253 & 0.176 & -0.077 & Belize & 0.169 & -0.333 & -0.503 \\
\hline Istael & 2001 & -0.020 & 0.275 & 0.295 & Benin & 0.186 & 0.351 & 0.165 \\
\hline Korea & 1997 & 0.033 & 0,337 & 0.304 & Bolivia & 0.033 & -0.162 & -0.195 \\
\hline Sri Lanka & 1998 & 0.052 & 0.127 & 0.075 & Butswana & -0.049 & 0.072 & 0.091 \\
\hline Mexico & 1995 & 0.297 & 0.419 & 0.122 & Bulgaria & 0.053 & -0.337 & -0.390 \\
\hline New Zealand & 2001 & $-0,148$ & 0.554 & 0.702 & Burkina Fass & 0.260 & 0.061 & -0.199 \\
\hline Norway & 2001 & 0.292 & 0.369 & 0.077 & Burundi & -0.138 & -0.164 & -0.026 \\
\hline Peru & 1989 & 0.240 & 0.727 & 0.487 & Cameruon & -10.194 & 0.338 & 0.532 \\
\hline Philippines & 2002 & -0.028 & 0.235 & 0.263 & Central African Republic & -0.021 & 0.207 & 0.228 \\
\hline South Africa & 2002 & 0.369 & 0.294 & -1.075 & Chad & -0.271 & 0.058 & 0.329 \\
\hline Sweden & 1995 & 0.085 & -0.112 & -1). 196 & China & -0.105 & 0.539 & 0.643 \\
\hline Thailand & 2006 & 0.100 & 0.088 & -0.012 & Congo, Rep. & 0.119 & 0.144 & 0.025 \\
\hline Turkey & 2000 & 0.114 & 0.270 & 0.156 & Costa Rica & 0.348 & 0.004 & -0.344 \\
\hline \multirow[t]{47}{*}{ United Kingdom } & 2000 & -0.425 & -0.133 & 0.292 & Cote d'Iwoire & -0.107 & 0.515 & 0.622 \\
\hline & & & & & Dominica & -0.280 & -0.378 & -0.098 \\
\hline & & & & & Egypt & 0.014 & 0,082 & 0.069 \\
\hline & & & & & Fiji & 0.004 & 0.248 & 0.243 \\
\hline & & & & & Finland & -10.447 & -0.219 & 0.228 \\
\hline & & & & & France & 0.012 & 0.583 & 0.570 \\
\hline & & & & & Gaboo & -0.336 & -0.113 & 0.223 \\
\hline & & & & & The Giamhia & 0.022 & -0.087 & -0.109 \\
\hline & & & & & Germany & 0,559 & 0.298 & -0.262 \\
\hline & & & & & Greece & -0.144 & 0.081 & 0.225 \\
\hline & & & & & Grenada & -10303 & -0.472 & .0 .169 \\
\hline & & & & & Geinea-Bissaa & 0.106 & -0.229 & -0.335 \\
\hline & & & & & Guyana & 0.183 & 0.485 & 0.302 \\
\hline & & & & & India & 0.260 & -0.104 & -0.365 \\
\hline & & & & & Ireland & 0.017 & -12.268 & -0.285 \\
\hline & & & & & ftaly & 0.028 & 0.493 & 0.465 \\
\hline & & & & & Japan & 0.063 & -0.569 & $-0,632$ \\
\hline & & & & & Jordan & 0.730 & 0.1111 & -0.619 \\
\hline & & & & & Kenya & 0.005 & 0.488 & 0.483 \\
\hline & & & & & Madagascar & 0.047 & 0.267 & 0.220 \\
\hline & & & & & Malawi & 0.065 & 0.074 & 0.010 \\
\hline & & & & & Malaysia & -0.083 & 0.026 & 0.109 \\
\hline & & & & & Mali & 0.243 & 0,011 & -0.232 \\
\hline & & & & & Mewritania & 0.310 & 0.211 & -0.099 \\
\hline & & & & & Maunitius & -1) 223 & 0.276 & 0.499 \\
\hline & & & & & Morosce & 0.086 & 0.098 & $-0,184$ \\
\hline & & & & & Netherlands & 0.600 & 0.283 & -0.317 \\
\hline & & & & & Nepal & -0.006 & 0.284 & 0.289 \\
\hline & & & & & Niger & 0.183 & 0.061 & -0.121 \\
\hline & & & & & Nigeria & 0.278 & -0.309 & -0.587 \\
\hline & & & & & Pakistan & -0.365 & $=0.118$ & 0.247 \\
\hline & & & & & Papua New Guinea & $-0.00 ?$ & 0.009 & 0.015 \\
\hline & & & & & Poctugal & 0.251 & 0.060 & -0.190 \\
\hline & & & & & Sentegal & 0.326 & -0.106 & -0.432 \\
\hline & & & & & Seychelles: & 0.203 & -0.357 & $-0,560$ \\
\hline & & & & & Siema Leone & -0.083 & 0.424 & 0.507 \\
\hline & & & & & Singapore & -10.078 & 0.008 & 0,086 \\
\hline & & & & & Spain & -0.047 & 0.401 & 0.448 \\
\hline & & & & & Switzerland & -10.152 & 0.414 & 0.566 \\
\hline & & & & & Tago & 0.125 & 0.414 & 0.290 \\
\hline & & & & & Trinidad and Tobago & 0.091 & 0.154 & 0.062 \\
\hline & & & & & Tunisia & 0.191 & -0.044 & -0.236 \\
\hline & & & & & Uganda & 0,339 & -0.227 & -0.566 \\
\hline & & & & & United States. & -0.029 & 0.397 & 0.426 \\
\hline & & & & & Uruguay & -1) 227 & -0.171 & 0.056 \\
\hline & & & & & Veneruela & 0.202 & 0.468 & 0.266 \\
\hline & & & & & Zambia & -10.144 & 0.267 & 0.411 \\
\hline Mean & & 0.151 & 0.257 & 0,105 & Mean & 0,052 & 0.082 & 0.030 \\
\hline
\end{tabular}

Correlation ooefficionts are 10-year moving zyerages of arnual data. For noc-inflation targeting countries the pre- and post-inflation tarneting periods are pre- and post-1999, which is the mean (and median) year of inflation targeting adoption by adopting coantries. The cyclical components have been estimated using the Hodrick-Pressott Filier. A positive (negative) correlation indicates countercyelical (procyclical) monctary policy. 
TABLE 2

PROBIT ESTIMATES OF PROPENSITY SCORES FOR ADOPTING INFLATION TARGETING

\begin{tabular}{|c|c|c|c|c|c|}
\hline & Baseline & $\begin{array}{l}\text { Add } \\
\text { currency } \\
\text { crisis }\end{array}$ & $\begin{array}{c}\text { Drop } \\
\text { High-Inflation } \\
\text { Countries }\end{array}$ & $\begin{array}{l}\text { Industrial } \\
\text { countries }\end{array}$ & $\begin{array}{c}\text { Developing } \\
\text { countries }\end{array}$ \\
\hline Lagged inflation & $\begin{array}{l}-0.0421^{* * *} \\
(0.0043)\end{array}$ & $\begin{array}{l}-0.0401^{* * *} \\
(0.0045)\end{array}$ & $\begin{array}{l}-0.0584^{* * *} \\
(0.0154)\end{array}$ & $\begin{array}{l}-0.0512 * * * \\
(0.0150)\end{array}$ & $\begin{array}{l}-0.0508^{* * *} \\
(0.0068)\end{array}$ \\
\hline GDP per capita growth & $\begin{array}{l}0.0142^{* *} \\
(0.0065)\end{array}$ & $\begin{array}{l}0.0133^{* *} \\
(0.0063)\end{array}$ & $\begin{array}{l}0.0129^{* *} \\
(0.0062)\end{array}$ & $\begin{array}{l}-0.0363 \\
(0.0260)\end{array}$ & $\begin{array}{l}0.0240^{* * *} \\
(0.0078)\end{array}$ \\
\hline Public debt & $\begin{array}{l}-0.0075^{* * *} \\
(0.0010)\end{array}$ & $\begin{array}{l}-0.0076^{* * * *} \\
(0.0010)\end{array}$ & $\begin{array}{l}-0.0077^{* * * *} \\
(0.0010)\end{array}$ & $\begin{array}{l}-0.0089^{* * *} \\
(0.0019)\end{array}$ & $\begin{array}{l}-0,0065^{* * *} \\
(0.0012)\end{array}$ \\
\hline Trade openness & $\begin{array}{l}0.0036^{* * *} \\
(0.0011)\end{array}$ & $\begin{array}{l}0.0036^{* * * *} \\
(0.0010)\end{array}$ & $\begin{array}{l}0.0036^{* * *} \\
(0.0011)\end{array}$ & $\begin{array}{l}-0.0119^{* * * *} \\
(0.0018)\end{array}$ & $\begin{array}{l}-0.0026^{*} \\
(0.0015)\end{array}$ \\
\hline Financial openness & $\begin{array}{l}0.0951^{* * *} \\
(0.0240)\end{array}$ & $\begin{array}{l}0.1008^{* * *} \\
(0.0324)\end{array}$ & $\begin{array}{l}0.0901^{* * *} \\
(0.0240)\end{array}$ & $\begin{array}{l}-0.0545 \\
(0.0796)\end{array}$ & $\begin{array}{l}0.1967^{* * *} \\
(0.0286)\end{array}$ \\
\hline Exchange rate regime & $\begin{array}{l}0.5671^{* * *} \\
(0.0323)\end{array}$ & $\begin{array}{l}0.5800^{* * *} \\
(0.0335)\end{array}$ & $\begin{array}{l}0.5810^{* * *} \\
(0.0336)\end{array}$ & $\begin{array}{l}0.6044^{* * *} \\
(0.0573)\end{array}$ & $\begin{array}{l}0.7030^{* * *} \\
(0.0554)\end{array}$ \\
\hline Financial development & $\begin{array}{l}0.0033^{* * *} \\
(0.0009)\end{array}$ & $\begin{array}{l}0.0034^{* * *} \\
(0.0009)\end{array}$ & $\begin{array}{l}0.0033^{* * *} \\
(0.0009)\end{array}$ & $\begin{array}{l}0.0061^{* * *} \\
(0.0013)\end{array}$ & $\begin{array}{l}0.0060^{* * *} \\
(0.0015)\end{array}$ \\
\hline Financial crisis & & $\begin{array}{l}-0.24035 \\
(0.1496)\end{array}$ & $\begin{array}{l}-0.2353 \\
(0.1503)\end{array}$ & $\begin{array}{l}-0.1950 \\
(0.2461)\end{array}$ & $\begin{array}{l}-0.3554^{*} \\
(0.2082)\end{array}$ \\
\hline Intercept & $\begin{array}{l}-2.2977^{* * *} \\
(0.1192)\end{array}$ & $\begin{array}{l}-2.3105^{* * * *} \\
(0.1120)\end{array}$ & $\begin{array}{l}-2.3112 * * * \\
(0.1203)\end{array}$ & $\begin{array}{l}-2.6898^{* * *} \\
(0.3089)\end{array}$ & $\begin{array}{l}-2.2982 * * * \\
(0.1460)\end{array}$ \\
\hline Psuedo $\mathrm{R}^{2}$ & 0.251 & 0.253 & 0.248 & 0.222 & 0.222 \\
\hline Observations & 2,818 & 2,817 & 2,756 & 750 & 750 \\
\hline
\end{tabular}


TABLE 3

MATCHING ESTIMATE OF THE TREATMENT EFFECT ON THE CYCLICALITY OF MONETARY POLICY

\begin{tabular}{|c|c|c|c|c|c|c|c|}
\hline & \multicolumn{7}{|l|}{ Matching methods } \\
\hline & \multirow[t]{2}{*}{$\begin{array}{l}\text { Nearest neighbour } \\
\text { matching }\end{array}$} & \multirow[t]{2}{*}{$\begin{array}{l}\text { Three- } \\
\text { nearest neighbour } \\
\text { matching }\end{array}$} & \multicolumn{3}{|c|}{ Radius matching } & \multirow[t]{2}{*}{$\begin{array}{l}\text { Local linear } \\
\text { regression } \\
\text { matching }\end{array}$} & \multirow[t]{2}{*}{$\begin{array}{l}\text { Kernal } \\
\text { matching }\end{array}$} \\
\hline & & & $\mathrm{r}=0.01$ & $\mathrm{r}=0.03$ & $\mathrm{r}=0.05$ & & \\
\hline Baseline ATT & $\begin{array}{l}0.1112^{* *} \\
(0.0396)\end{array}$ & $\begin{array}{l}0.1165^{* * *} \\
(0.0360)\end{array}$ & $\begin{array}{l}0.1045^{* * *} \\
(0.0308)\end{array}$ & $\begin{array}{l}0.1119^{* * *} \\
(0.0286)\end{array}$ & $\begin{array}{l}0.1120^{* * *} \\
(0.0287)\end{array}$ & $\begin{array}{l}0.1028^{* * *} \\
(0.0274)\end{array}$ & $\begin{array}{l}0.1118 * * * \\
(0.0288)\end{array}$ \\
\hline Add financial crisis ATT & $\begin{array}{l}0.1038^{* * * *} \\
(0.0290)\end{array}$ & $\begin{array}{l}0.1013^{* *} \\
(0.0342)\end{array}$ & $\begin{array}{l}0.1050^{\text {**** }} \\
(0.0287)\end{array}$ & $\begin{array}{l}0.1121^{* * *} \\
(0.0274)\end{array}$ & $\begin{array}{l}0.1157^{* * * *} \\
(0.0287)\end{array}$ & $\begin{array}{l}0.1054^{\text {**** }} \\
(0.0274)\end{array}$ & $\begin{array}{l}0.1135^{* * *} \\
(0.0275)\end{array}$ \\
\hline Drop high inflation ATT & $\begin{array}{l}0.1119^{* *} \\
(0.0407)\end{array}$ & $\begin{array}{l}0.1173^{* * *} \\
(0.0364)\end{array}$ & $\begin{array}{l}0.1064^{* * *} \\
(0.0305)\end{array}$ & $\begin{array}{l}0.1130^{* * *} \\
(0.0288)\end{array}$ & $\begin{array}{l}0.1129^{* * *} \\
(0.0291)\end{array}$ & $\begin{array}{l}0.1038^{* * *} \\
(0.0290)\end{array}$ & $\begin{array}{l}0.1127 * * 6 \\
(0.0298)\end{array}$ \\
\hline Industrial countries ATT & $\begin{array}{l}0.0852^{* *} \\
(0.0379)\end{array}$ & $\begin{array}{l}0.1013^{* *} \\
(0.0342)\end{array}$ & $\begin{array}{l}0.1050^{* * *} \\
(0.0287)\end{array}$ & $\begin{array}{l}0.1121 * * * \\
(0.0275)\end{array}$ & $\begin{array}{l}0.1157 * 8 * \\
(0.0287)\end{array}$ & $\begin{array}{l}0.1054^{* * *} \\
(0.0274)\end{array}$ & $\begin{array}{l}0.1135^{* * *} \\
(0.0275)\end{array}$ \\
\hline Developing countries ATT & $\begin{array}{c}0.0691^{*} \\
(0.0348)\end{array}$ & $\begin{array}{l}0.1037^{* *} \\
(0.0362)\end{array}$ & $\begin{array}{l}0.1073^{* * *} \\
(0.0315)\end{array}$ & $\begin{array}{l}0.1122^{* * *} \\
(0.0303)\end{array}$ & $\begin{array}{l}0.1155^{* * *} \\
(0.0292)\end{array}$ & $\begin{array}{l}0.1189^{* * *} \\
(0.0281)\end{array}$ & $\begin{array}{l}0.1149 * * \\
(0.0288)\end{array}$ \\
\hline
\end{tabular}

Notes

A 0.06 fixed bandwidth and an Epanechnikov kernal are used for kernal and local linear regression matching. Bootstrapped standard errors are reported in parenthesis, ***, ** and $*$ indicate significance at the $1 \%, 5 \%$ and $10 \%$ levels, respectively. 